\title{
Bacterioplankton Activity in a Meso-eutrophic Subtropical Coastal Lagoon
}

\author{
Maria L. Schmitz Fontes $\left(\mathbb{D},{ }^{1,2}\right.$ Heloísa Fernandes, ${ }^{3}$ Manoela Brandão, ${ }^{1}$ \\ Mariana Coutinho Hennemann, ${ }^{1}$ Raquel Aparecida Loss, ${ }^{4}$ \\ Valdelúcia Maria Alves de Souza Grinevicius, ${ }^{5}$ Denise Tonetta, ${ }^{1}$ Karina Cesca, ${ }^{4}$ \\ Mônica Hessel Silveira, ${ }^{1}$ Mara Bedin, ${ }^{1}$ Derce Recouvreux, ${ }^{4}$ \\ and Regina Vasconcellos Antônio ${ }^{6}$ \\ ${ }^{1}$ Departamento de Ecologia e Zoologia, Centro de Ciências Biológicas, Universidade Federal de Santa Catarina, Trindade, \\ 88040-970 Florianópolis, SC, Brazil \\ ${ }^{2}$ PPGOCEANO, Departamento de Geociências, Centro de Filosofia e Ciências Humanas, \\ Universidade Federal de Santa Catarina, Trindade, 88040-970 Florianópolis, SC, Brazil \\ ${ }^{3}$ Departamento de Engenharia Sanitária, Centro Tecnológico, Universidade Federal de Santa Catarina, \\ Trindade, 88040-970 Florianópolis, SC, Brazil \\ ${ }^{4}$ Departamento de Engenharia Química e Engenharia de Alimentos, Centro Tecnológico, \\ Universidade Federal de Santa Catarina, Trindade, 88040-970 Florianópolis, SC, Brazil \\ ${ }^{5}$ Departamento deBioquímica, Centro de Ciências Biológicas, Universidade Federal de Santa Catarina, Trindade, \\ 88040-970 Florianópolis, SC, Brazil \\ ${ }^{6}$ Campus Araranguá, Universidade Federal de Santa Catarina, Trindade, 88000-000 Araranguá, SC, Brazil
}

Correspondence should be addressed to Maria L.Schmitz Fontes; fontesml@me.com

Received 11 April 2018; Revised 20 July 2018; Accepted 9 August 2018; Published 3 October 2018

Academic Editor: Hidetoshi Urakawa

Copyright (c) 2018 Maria L. Schmitz Fontes et al. This is an open access article distributed under the Creative Commons Attribution License, which permits unrestricted use, distribution, and reproduction in any medium, provided the original work is properly cited.

\begin{abstract}
The aim of this study was to investigate whether the bacterioplankton activity in the meso-eutrophic Conceição Lagoon would increase significantly under allochthonous inputs of inorganic nutrients and organic carbon. Abundance and biomass of bacterioplankton were evaluated under three treatments: light (14 h light $/ 10 \mathrm{~h}$ dark), complete darkness (dark-control), and nutrient $(\mathrm{C}+\mathrm{N}$ $+\mathrm{P}$-dark, $100: 10: 1$ ) enrichments during $72 \mathrm{~h}$. Nutrient enrichments promoted a significant increase in abundance (maximum of $19.0 \times 10^{9}$ cells $\cdot \mathrm{L}^{-1}$ in the first 32 hours) and biomass of the heterotrophic bacterioplankton, which induced the formation of large clusters. Bacterial biomass remained constant in the non-enriched incubations (dark-control and light). Bacterial growth rates were significantly higher after nutrient additions $\left(1.35 \mathrm{~d}^{-1}\right)$, followed by control $\left(0.79 \mathrm{~d}^{-1}\right)$, and light $\left(0.63 \mathrm{~d}^{-1}\right)$ treatments, which were statistically equal $(p>0.05)$. Bacterial production rates were also significantly higher under nutrient additions $\left(1.28 \mathrm{~d}^{-1}\right)$, compared to the control and light $\left(0.50 \mathrm{~d}^{-1}\right.$ and $0.44 \mathrm{~d}^{-1}$, respectively), demonstrating that bacterial growth and production in this meso-eutrophic lagoon are under an immediate "bottom-up" regulation, followed by a potential top-down effect. These facts reinforce the urgency on improving the local wastewater management plan in order to prevent further expansion of anoxic waters.
\end{abstract}

\section{Introduction}

The comprehension of the pelagic bacterioplankton abundance and activity in coastal aquatic environments is of major importance in order to predict shifts in the microbial communities in response to frequent changes in such systems [1]. The inputs of organic material and inorganic nutrients to coastal lagoons mainly from watershed runoffs, infiltration, precipitation, air and sea exchanges can have a direct influence on activity and composition of microbial communities and, consequently, in the ecosystem function $[2,3]$. Coastal lagoons are located in the transitional region between terrestrial and marine environments, 
and are considered highly dynamic environments, subjected to abrupt changes in physicochemical variables, residence times, and recipients of multiple sources of nutrients $[3,4]$.

Heterotrophic bacteria play important roles in the remineralization and transformation processes between dissolved organic carbon (DOC) and particulate organic carbon (POC) $[5,6]$, which will then be available to higher trophic levels through the microbial loop [7]. The functionality of bacterioplankton, predominantly net sink or link of carbon in a system, will depend on the chemical composition of the DOC pool [8], if predation is absent or minimized.

However, the cause-effect relationship of labile carbon forms and/or inorganic nutrients on the bacterial activity is not clear yet. Some studies have shown a positive effect of dissolved inorganic nitrogen and phosphate enrichment on marine bacterial growth [9-12], while others demonstrated no effect [13]. With the simultaneous addition of inorganic nutrients and glucose, several studies have shown a significant response in bacterial abundance and production [14-17]. The heterogeneity observed in the results has been related to the different trophic states of each environment [9].

In coastal ecosystems such as the Conceição Lagoon, a meso-eutrophic coastal lagoon [18], additional inputs of allochthonous material can stimulate heterotrophic microorganisms and consequently lead to oxygen depletion [19-21]. Anoxia occurrence has increased significantly in the last 15 years in the central area of the lagoon [18], and its trophic state has changed from oligo-mesotrophic to mesoeutrophic in the same period of time [18]. Thus, we hypothesized that bacterioplankton activity, determined here by bacterial production and growth, would increase in this meso-eutrophic system if exposed to simultaneous external inorganic nutrients' sources and organic matter.

\section{Materials and Methods}

2.1. Water Sampling and Study Site. A $20 \mathrm{~L}$ water sample was collected at subsurface in the central sector of Conceição Lagoon on the 2nd of November, 2011, and was kept at low temperature until transported to the laboratory. The lagoon is located between $27^{\circ} 30^{\prime} 17^{\prime \prime}$ and $27^{\circ} 37^{\prime} 36^{\prime \prime} \mathrm{S}$ and $48^{\circ} 25^{\prime} 30^{\prime \prime}$ and $48^{\circ} 29^{\prime} 54^{\prime \prime} \mathrm{W}$ (Figure 1).

Conceição Lagoon is connected to the Atlantic Ocean by a $2 \mathrm{~km}$ long channel, which drives a salinity variability in the central sector from 17.6 up to $30[19,22]$. Water temperature during the experiment was maintained $24^{\circ} \mathrm{C}$; usual dissolved inorganic nitrogen (ammonium + nitrate + nitrite) and dissolved inorganic phosphorus (phosphate) concentrations range between 1.0 and $13.2 \mu \mathrm{M}$ and between 0.09 and $0.52 \mu \mathrm{M}$, respectively; with average DIN:DIP ratios above 25:1 [22]. Chlorophyll a concentrations average between 3.5 and $4.0 \mu \mathrm{g} \cdot \mathrm{L}^{-1}[19,20,22]$. Additionally, continuous runoffs rich in untreated (raw) domestic sewage flow directly into its water body $[22,23]$. The average domestic sewage volume discharged into the system has been calculated to be around $160 \mathrm{~m}^{3}$ of sewage month ${ }^{-1}$, corresponding to $300 \mathrm{~kg}$ (biological oxygen demand, $\mathrm{BOD}_{5}$ day $)^{-1}$ [24]. Due to this elevated sewage input, a considerable increase in dissolved inorganic nitrogen (ammonium, nitrite, and nitrate) concentrations has been observed in the lagoon water since 1980s [25].

\subsection{Culture Preparation and Experimental Procedure.} Water aliquots were collected from Conceição Lagoon and carefully filtered through a cellulose acetate membrane (Millipore $47 \mathrm{~mm}$ in diameter and $0.2 \mu \mathrm{m}$ in pore size) in the laboratory. One liter of the filtered water or medium (dilution of the sample resulted in a reduction in the amount of grazers [14]) was transferred onto each of three sterile glass recipients resulting in $70 \%$ of filtered medium and $30 \%$ of inoculum (whole water-no previous filtration), equivalent to a volume of $1.43 \mathrm{~L}$ per replicate. Bacterioplankton cultures received the following labels according to the treatment: (1) light (in situ light intensity and photoperiod: $14 \mathrm{~h}$ light, $10 \mathrm{~h}$ dark, room temperature); (2) control (dark, room temperature); and (3) nutrients $\left(\mathrm{C}+\mathrm{N}+\mathrm{P}=\right.$ glucose, $\mathrm{NH}_{4} \mathrm{Cl}$, and $\mathrm{K}_{2} \mathrm{HPO}_{4}$ additions at final concentrations of $100 \mu \mathrm{M} \mathrm{C}$ : $10 \mu \mathrm{M} \mathrm{N}: 1 \mu \mathrm{M}$ P, dark, room temperature). All treatments were kept under the described conditions for $72 \mathrm{~h}$. The reason why control and nutrients' treatments were kept in the dark was to prevent the accumulation of autotrophic biomass (presence of photoautotrophic bacteria and picoeukaryotes) throughout the experiment, which would interfere with the results by competition or release of extracellular DOC. On the other hand, light treatment was important for the effects of light/dark cycles on bacterial activity when compared to complete darkness.

2.3. Bacterial Counts and Biomass. Aliquots of $15 \mathrm{ml}$ were taken from each treatment at $12 \mathrm{~h}$ intervals and fixed with PFA (paraformaldehyde) at $2 \%$ (final concentration), making 7 estimates for each treatment $\left(t_{0}, t_{12}, t_{24}, t_{36}, t_{48}, t_{60}\right.$, and $\left.t_{72}\right)$. The aliquots were used to determine bacterial abundance, biomass, and size or biovolume. One $\mathrm{ml}$ of aliquots from each treatment was filtered through $0.2 \mu \mathrm{m}$ dark polycarbonate membranes (diameter of $25 \mathrm{~mm}$ ) (Millipore) and stained with 4',6-diamidino-2-phenylindole (DAPI) for $15 \mathrm{~min}\left(1 \mu \mathrm{g} \cdot \mathrm{ml}^{-1}\right.$, final concentration).

Filters were mounted onto slides, and bacterial cells were counted using an epifluorescence microscope (Olympus BX40) [26]. From each filter, ten random fields were counted and at least 200 bacterial cells were measured. Length, width, elongation, and area of each cell were measured using the freeware "UTHSCSA Image Tool" (University of Texas Health Science Center, San Antonio, Texas, US) [27]. Bacterial biovolume was calculated from length and width measurements and biomass as function of biovolume using the following algorithm: $B=120 \mathrm{~V}^{0.72}$, where $B=$ biomass; $V=$ biovolume $\left(\mu \mathrm{m}^{3}\right) ; 120=$ conversion factor in $\mathrm{fg} \cdot \mathrm{C} \cdot \mu \mathrm{m}^{-3}$ [28]. Total biomass was calculated by multiplying the average cellular biomass by bacterial abundance.

2.4. Data Analysis. Bacterial growth was calculated as the increase in cellular density from the beginning to the end of the exponential growth period. Bacterial production was calculated in the same manner using bacterial biomass data by the time. 


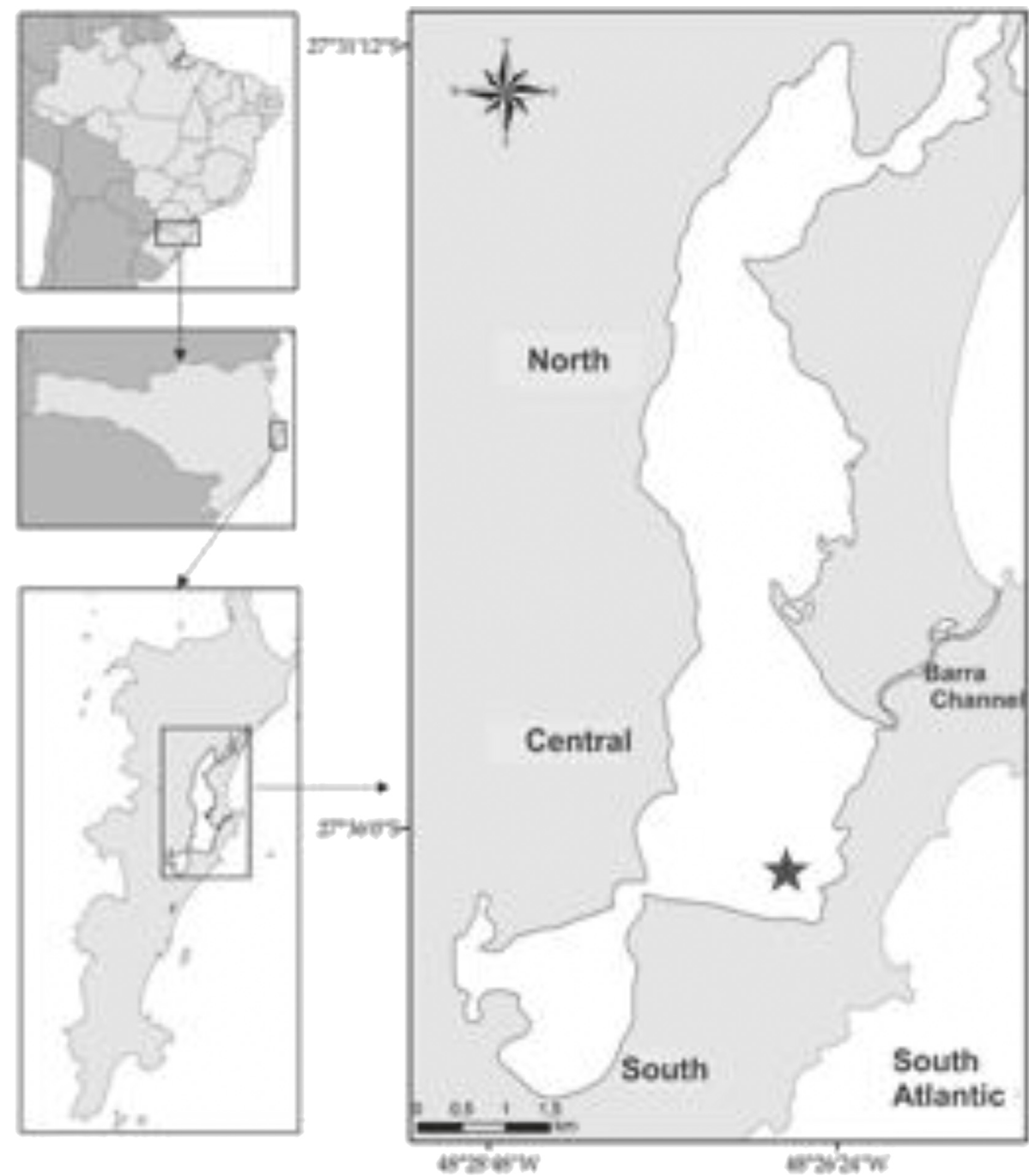

Figure 1: Location of the Conceição Lagoon (grey), Santa Catarina Island, Florianópolis, Brazil. Sampling site is represented by a star symbol (adapted from Fontes and Abreu [19]).

Bacterioplankton specific growth rates $(\mu)$ and biomass production rates were calculated as the slope of the linear regression of ln-transformed bacterial abundance or biomass with time during the exponential growth [29]. Daily growth rate (daily $\mu$ ) and daily bacterial production rates were obtained by multiplying the hourly growth rate by 24 . Doubling time was calculated by dividing $0.69(\ln 2)$ by the daily $\mu$. Comparison between bacterial growth rates and production rates (linear regression angular coefficient) was made by analysis of covariance (ANCOVA), with subsequent multiple comparisons performed using Tukey's test with a statistical significance level of $p \leq 0.05$. Density, biomass, and biovolume means were compared by analysis of variance (ANOVA) or $t$ test, if the case, of $(\log +1)$-transformed data, followed by Tukey's test (significance level of $p \leq 0.05$ ) [30,31]. Statistical tests were conducted using Statistica 7 software.

\section{Results}

Samples showed different abundance and biomass values among treatments and time. The mean number of cells (cells $\cdot \mathrm{L}^{-1}$ ) in each treatment after $72 \mathrm{~h}$ of incubation was higher in the nutrient treatment $\left(7.44 \times 10^{9} \pm 2.55 \times 10^{9}\right.$ cells $\left.\cdot \mathrm{L}^{-1}\right)$, followed by the dark-control $\left(3.00 \times 10^{9} \pm 8.04 \times 10^{8}\right.$ cells $\left.\cdot \mathrm{L}^{-1}\right)$ and light flasks $\left(1.77 \times 10^{9} \pm 2.08 \times 10^{8}\right.$ cells $\left.\cdot \mathrm{L}^{-1}\right)$. Bacterial abundance increased exponentially until $36 \mathrm{~h}$ (maximum $1.9 \times 10^{10}$ cells $\cdot \mathrm{L}^{-1}$ ), followed by a decrease and a second small increase between 60 and $72 \mathrm{~h}$ in the nutrient treatment. In the dark-control treatment, the number of cells increased until $48 \mathrm{~h}$ (maximum $7.18 \times 10^{9}$ cells. $\mathrm{L}^{-1}$ ). In the light flasks, samples showed a lower abundance when compared to the other treatments and maintained approximately constant values throughout the experiment (Figure 2).

Considering cells arrangement in each treatment, there was an increase in the occurrence of cells clustering and size after $36 \mathrm{~h}$ of incubation only in the nutrient enrichment, with up to 200 cells clustered together (Figure 3). In addition, the abundance of filamentous bacteria increased between 12 and $24 \mathrm{~h}$ in the nutrients treatment, while in the dark-control, a smaller and delayed increase occurred between 36 and $48 \mathrm{~h}$. In the light treatment, constant numbers of filamentous bacteria were observed throughout the 


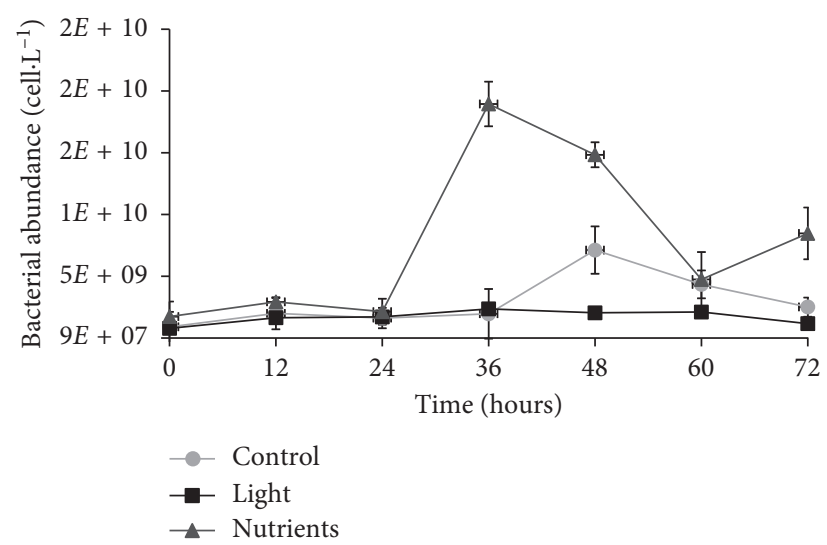

FiguRE 2: Bacterial abundance (mean \pm standard error) in the three treatments during the $72 \mathrm{~h}$ incubation period. Treatments: darkcontrol $=$ control, $14 \mathrm{~h}$ light $/ 10 \mathrm{~h}$ dark cycle $=$ light, and dark $\mathrm{C}+\mathrm{N}+\mathrm{P}$ enrichment $=$ nutrients.

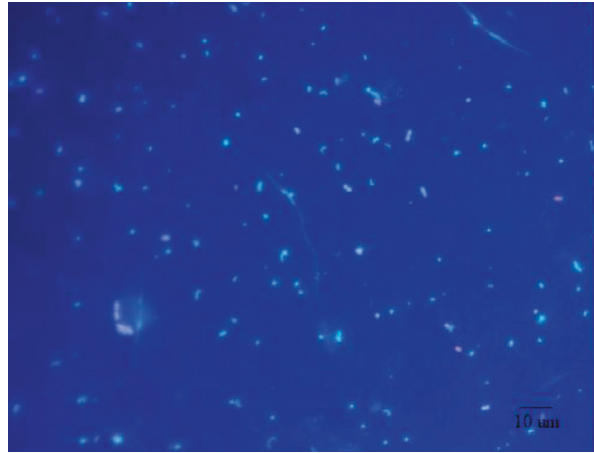

(a)

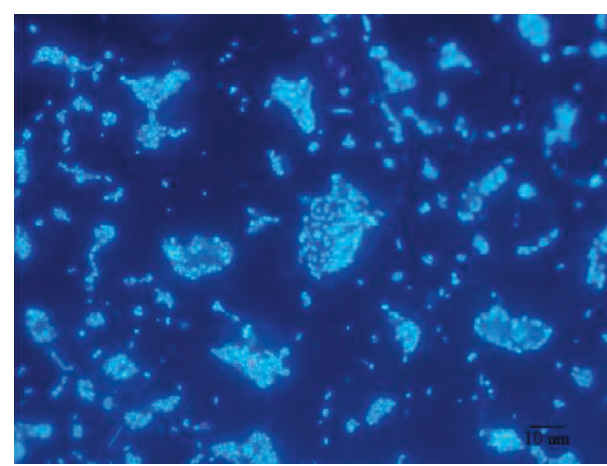

(b)

FIGURE 3: Epifluorescence microphotographs (1000x) of bacteria stained with DAPI at $12 \mathrm{~h}(\mathrm{a})$ and $72 \mathrm{~h}(\mathrm{~b})$ of the experiments in the $\mathrm{C}+\mathrm{N}+\mathrm{P}$ treatment.

experiment (Figure 4). However, no significant differences were observed concerning filamentous bacterial abundance among treatments (one-way ANOVA, $p>0.05$ ). Considering the relative abundance of filamentous bacteria, a stronger contribution of this portion of the community was detected in the light and dark-control flasks (5.6\% and $7.1 \%$, respectively), against $2.5 \%$ contribution in the ones that received nutrients.

The bacterial size estimated as cellular biovolume $\left(\mu \mathrm{m}^{3}\right)$ has been used to calculate cellular biomass in function of $\mathrm{C}$ availability $\left(\mu \mathrm{g} \cdot \mathrm{C} \cdot \mathrm{cell}^{-1}\right)$. As a result, mean cellular biovolume ranged between 6.45 and $13.65 \mu \mathrm{m}^{3}$, and biomass, as a consequence, between 417.82 and $678.36 \mu \mathrm{g} \cdot \mathrm{C} \cdot \mathrm{cell}^{-1}$. The highest averages of biovolume were observed in the nutrients treatment at $36 \mathrm{~h}\left(13.65 \mu \mathrm{m}^{3}\right)$ and in the light at $24 \mathrm{~h}\left(13.58 \mu \mathrm{m}^{3}\right)$ (Figure 5). High oscillations in the mean biovolume can be attributed to different contributions of filamentous bacteria and to the presence of different bacteria morphotypes. However, biovolume was not significantly different among treatments (one-way ANOVA, $p>0.05$ ) (Table 1). On the other hand, considering total biomass (carbon per volume unit $\left(\mathrm{mg} \cdot \mathrm{C} \cdot \mathrm{L}^{-1}\right)$ ), the highest biomass was registered in the nutrients treatment, especially between 24 and $36 \mathrm{~h}$ (with a peak of $12.3 \mathrm{mg} \cdot \mathrm{C} \cdot \mathrm{L}^{-1}$ ) (Figure 6 ), similarly to what was shown for bacterial abundance (Figure 2).
Bacterial abundance and biomass were higher under nutrients additions when compared to the dark-control and light treatments (one-way ANOVA, $p<0.05$ ) (Table 1). Bacterial growth rates were $0.79 \mathrm{~d}^{-1}, 1.34 \mathrm{~d}^{-1}$, and $0.63 \mathrm{~d}^{-1}$ in the dark-control, nutrients, and light treatments, respectively. Bacterial production rates oscillated from 0.44 to $1.13 \mathrm{~d}^{-1}$ (Table 2). The ANCOVA result showed that bacterial growth and biomass production rates differed among treatments (ANCOVA: $F_{0.05 ;(1) ; 2 ; 9}=9.00$ for growth and ANCOVA: $F_{0.05 ;(1) ; 2 ; 9}=5.08$ for bacterial production). The difference among slopes was tested, and it was observed that bacterial growth and production were significantly higher in the nutrients treatment, while growth and production were similar in light and darkcontrol incubations (Table 2).

Doubling times $\left(0.51 \mathrm{~d}^{-1}, 0.87 \mathrm{~d}^{-1}\right.$, and $1.10 \mathrm{~d}^{-1}$ for nutrients, dark-control, and light, respectively) showed that the heterotrophic bacterial community went through two duplications per day in the nutrients treatment, while in natural conditions (dark-control treatment), bacterioplankton duplicated once a day (Table 2).

When changes in cellular biovolume and carbon biomass are considered, slightly different results were observed, since both nutrients and light treatments showed small increases in the parameters at the end of the $72 \mathrm{~h}$ incubation period. 


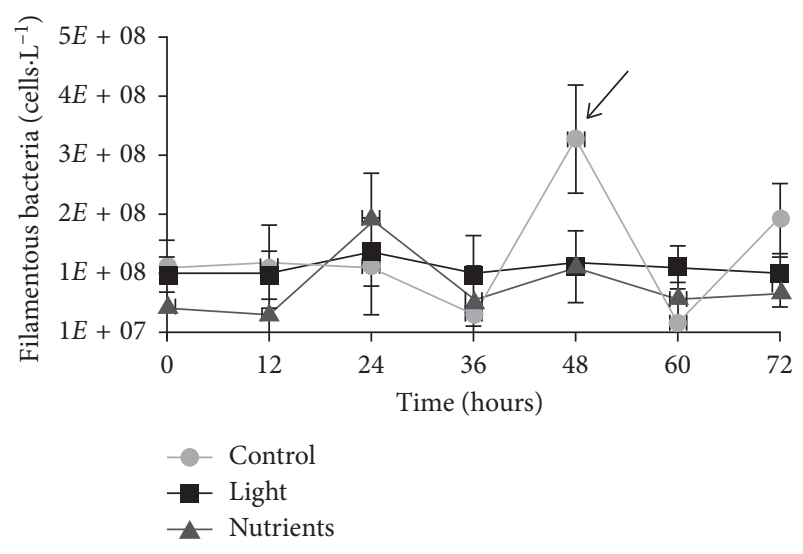

(a)

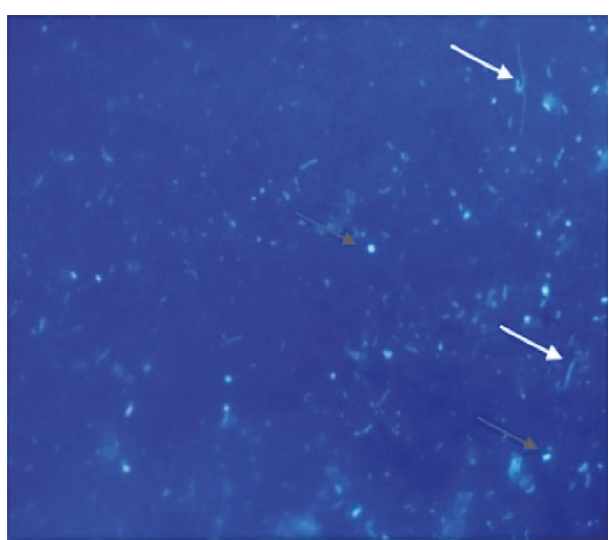

(b)

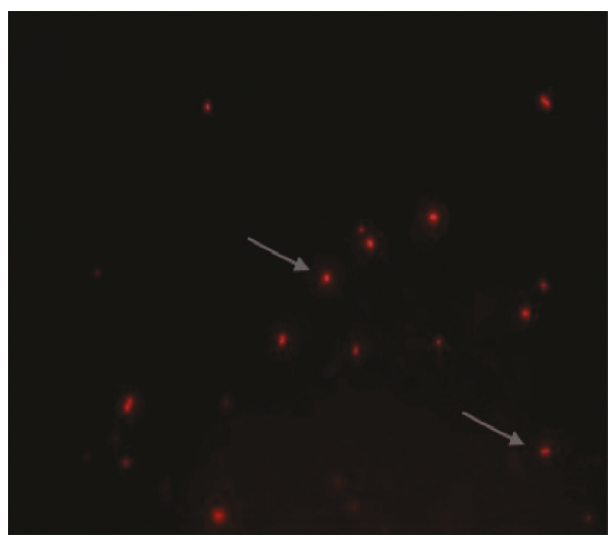

(c)

FIGURE 4: Filamentous bacterial abundance (mean \pm standard error) (a) in the three treatments during the $72 \mathrm{~h}$ incubation period. Treatments: dark-control $=$ control, $14 \mathrm{~h}$ light $/ 10 \mathrm{~h}$ dark cycle $=$ light, and dark $\mathrm{C}+\mathrm{N}+\mathrm{P}$ enrichment $=$ nutrients. Examples of filamentous bacteria (b) and cyanobacteria (c) present in the dark-control treatment at the $48 \mathrm{~h}$. (b) DAPI-stained cells, heterotrophic filamentous bacteria (indicated by white arrows). (c) Autofluorescence of cyanobacteria in red (indicated by grey arrows).

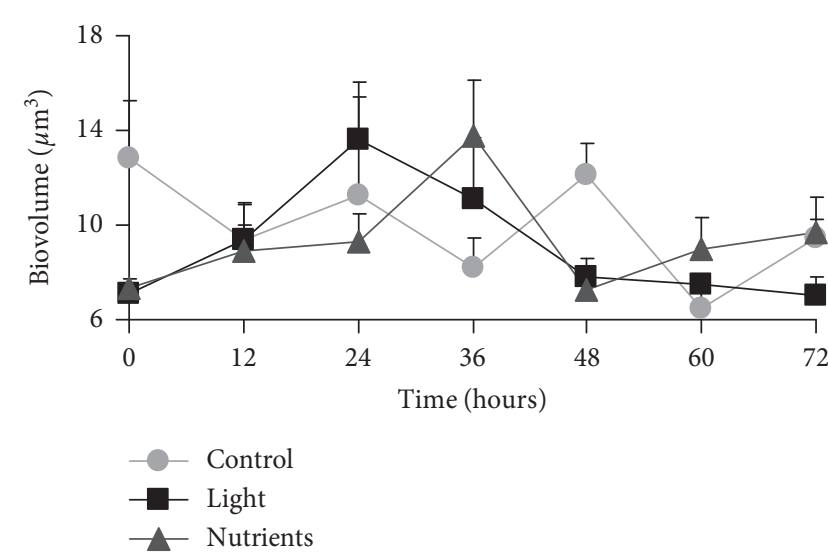

FIGURE 5: Cellular biovolume in $\mu \mathrm{m}^{3}$ (mean \pm standard error) in the three treatments during the $72 \mathrm{~h}$ incubation period. Treatments: dark-control $=$ control, $14 \mathrm{~h}$ light $/ 10 \mathrm{~h}$ dark cycle $=$ light, and dark $\mathrm{C}+\mathrm{N}+\mathrm{P}$ enrichment $=$ nutrients .

\section{Discussion}

Bacterioplankton activity in this meso-eutrophic lagoon was significantly stimulated after the addition of dissolved organic carbon and inorganic nutrients, demonstrating the
TABLE 1: Results of one-way ANOVA performed to test the effect of different treatments (dark-control, light, and dark $\mathrm{C}+\mathrm{N}+\mathrm{P}$ ) on bacterial abundance, biovolume, and biomass.

\begin{tabular}{lccccc}
\hline Parameter & & DF$^{*}$ & MS & $F$ & $p$ \\
\hline \multirow{2}{*}{ Density $\left(\right.$ cells $\left.\cdot \mathrm{L}^{-1}\right)$} & Treatment & 2 & 0.4710 & 5.3 & 0.0154 \\
& Error & 18 & 0.0890 & & \\
Biovolume $\left(\mu \mathrm{m}^{3}\right)$ & Treatment & 2 & 0.0031 & 0.3 & 0.7467 \\
& Error & 18 & 0.0105 & & \\
Biomass $\left(\mathrm{mg} \cdot \mathrm{L}^{-1}\right)$ & Treatment & 2 & 0.4734 & 4.6 & 0.0235 \\
& Error & 18 & 0.1017 & & \\
\hline
\end{tabular}

${ }^{*} \mathrm{DF}=$ degrees of freedom.

vulnerability of this system to external sources of organic and inorganic matter.

The average cellular size, $13 \mu \mathrm{m}^{3}$, did not vary significantly throughout the experiment; however, bacterial cells showed a great morphological variability. Naturally, isolated marine bacteria show low growth rates under environmental conditions [32]. These authors reported that cells with a biovolume of $0.008 \mu \mathrm{m}^{3}$ have growth rates of $0.3 \mathrm{~d}^{-1}$, while $0.3 \mu \mathrm{m}^{3}$ cells show growth rates of $1.4 \mathrm{~d}^{-1}$. The average biovolume found in our study was $13 \mu \mathrm{m}^{3}$, two orders of magnitude higher than usually found in marine environments. However, it is important to highlight the presence 


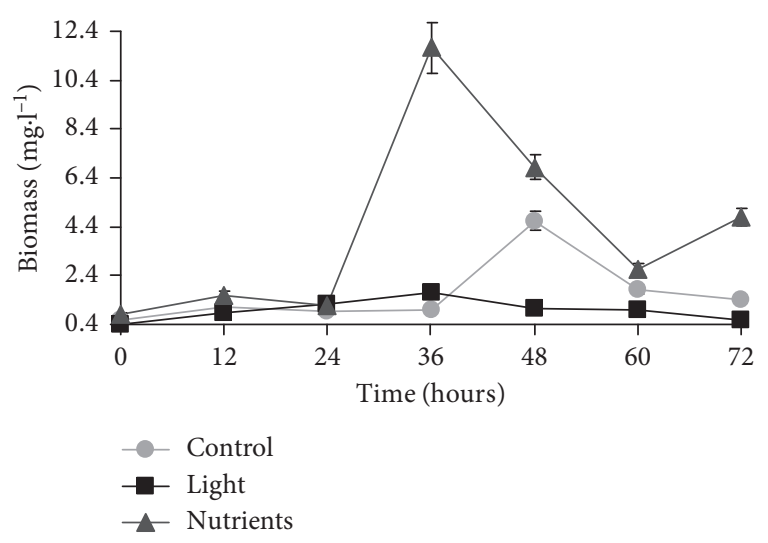

Figure 6: Bacterial biomass (mg.C. $\mathrm{L}^{-1}+$ standard error) in the three treatments during the $72 \mathrm{~h}$ incubation period. Treatments: darkcontrol $=$ control, $14 \mathrm{~h}$ light $/ 10 \mathrm{~h}$ dark cycle $=$ light, and dark $\mathrm{C}+\mathrm{N}+\mathrm{P}$ enrichment $=$ nutrients.

TABLE 2: Bacterial growth rates (hour ${ }^{-1}$ and day ${ }^{-1}$ ) and coefficient of determination $\left(R^{2}\right)$, production rates $\left(\right.$ hour $^{-1}$ and day $\left.{ }^{-1}\right)$ and coefficient of determination $\left(R^{2}\right)$, and doubling time for light, dark-control, and dark $\mathrm{C}+\mathrm{N}+\mathrm{P}$ treatments. Bacterial growth and production rates were determined from the slope of the linear regression of ln-transformed bacterial abundance or biomass versus time (from time zero to the end of the exponential growth phase).

\begin{tabular}{|c|c|c|c|c|c|c|c|}
\hline Treatment & Growth rate $\left(\mathrm{h}^{-1}\right)$ & Growth rate $\left(\mathrm{d}^{-1}\right)$ & $R^{2}$ & Production rate $\left(\mathrm{h}^{-1}\right)$ & Production rate $\left(\mathrm{d}^{-1}\right)$ & $R^{2}$ & Doubling time \\
\hline Light & $0.026^{\mathrm{b}}$ & 0.626 & 0.86 & $0.018^{\mathrm{b}}$ & 0.437 & 0.98 & 1.106 \\
\hline Dark-control & $0.033^{\mathrm{b}}$ & 0.789 & 0.74 & $0.021^{\mathrm{a}, \mathrm{b}}$ & 0.500 & 0.62 & 0.878 \\
\hline Dark $\mathrm{C}+\mathrm{N}+\mathrm{P}$ & $0.056^{\mathrm{a}}$ & 1.346 & 0.74 & $0.047^{\mathrm{a}}$ & 1.128 & 0.67 & 0.515 \\
\hline
\end{tabular}

Superscript letters indicate the result of ANCOVA and Tukey test for difference among slopes- $q 0.05$.

and the relative abundance of filamentous bacteria, especially around $48 \mathrm{~h}$ in the control treatment. The predominance of heterotrophic filamentous bacteria has already been described previously in the Conceição Lagoon as positively related to the coccoid cyanobacteria of genus Synechococcus [19], as shown in Figures 4(b) and 4(c). This has been described as a strategy to avoid predation, when bacteria alter their size towards filamentous forms when exposed to grazing pressure [33-35].

Some studies have suggested that viral lysis and predation by protists are the main regulators of bacterial growth and production, many times more important than resources availability [36-38]. However, in environments with $\mathrm{N}: \mathrm{P}$ ratios above the Redfield ratio, where phosphorous is the limiting resource, as in Conceição Lagoon [22, 23], bottomup control of bacterial growth and/or biomass has a much more important role than top-down control by bacterivory $[39,40]$. Therefore, grazing cannot be ignored as a secondary regulator on the activity of bacterioplankton. The significant decrease of bacteria abundance between 36 and $60 \mathrm{~h}$ in the nutrients treatment was concurrent with a slight decrease in the average bacterial biovolume, which is illustrated by the formation of several clusters of bacterial cells resulting on smaller biovolume when attached to each other. There are a few hypotheses for this outcome: predation scape strategy, increase proximity, and signaling among cells to overcome resource limitation.

In Conceição Lagoon, bacterial growth rates and production doubled after the addition of nutrients, compared to the dark-control and light treatments. In a study carried out with samples from the oligotrophic Sargasso Sea, the additions of nitrogen, phosphorus, and carbon resulted in increasing bacterial production by 7 to 15 times when compared to control or inorganic nutrient additions alone [14]. This finding reinforces that bacterioplankton of oligotrophic environments (under constant starvation and competition pressure with phytoplankton) responds much faster after simultaneous additions of inorganic nutrients and carbon than those of meso-eutrophic environments.

Previous studies have shown contradicting results on the effect of nutrients and carbon enrichment on bacterial growth and secondary production (e.g., [40-46]). For example, a significant increase on bacterial production after the addition of nutrients and carbon are reported in a fjord in Norway [47], whereas no significant changes were described in the oligo-mesotrophic Uchiumi Bay, Japan [13]. The best explanation for such heterogeneity in growth and productivity of aquatic bacteria has been described to be the ecosystem's trophic state, as the primary response of bacteria to eutrophication is to increase their specific growth rates [48]. The ecosystem's trophic state is related to variables that directly or indirectly correlate with the system's primary production: total organic matter, dissolved oxygen concentration, total phosphorus, light penetration, and phytoplankton biomass indicated by chlorophyll a concentration $[49,50]$. As Conceição Lagoon is under eutrophication, with persistent anoxic waters in the bottom of the central sector, the increase in aerobic respiration by microbes can be a major problem for the water quality of this ecosystem.

Thus, increasing nutrient loads ( $\mathrm{N}$ and $\mathrm{P}$ ) directly or indirectly (trophic state) will alter bacterial community 
composition by favouring certain bacterial populations that have the ability to rapidly consume these new available resources [51-55]. Our results show that bacterial activity remains unaltered when exposed to complete darkness $(t$ test - light $\mathrm{x}$ control - $p>0.05$ ), and that under additions of inorganic nutrients and organic carbon, the total bacterial activity doubles in the first 24 hours. Apparently, there is an indicative of strong competition for nutrients in Conceição Lagoon.

The present study shows similar activities for total (auto + heterotrophic) bacterioplankton and strict heterotrophic bacteria when neither inorganic nutrient nor carbon is added onto the lagoon. Nevertheless, bacterioplankton growth and production were stimulated by carbon, nitrogen, and phosphorous additions, indicating that bacterioplankton biomass in this meso-eutrophic coastal lagoon is likely to be primarily bottom-up regulated. This study suggests that allochthonous carbon and inorganic nutrients via untreated sewage inputs or rainstorm runoffs into the lagoon have the potential to promote a quick response of bacterioplankton and, thus, increase the area and persistency of the "dead zones" within the lagoon. Our results reinforce the importance of an effective waste management plan for the area.

\section{Data Availability}

The data used to support the findings of this study are available from the corresponding author upon request.

\section{Conflicts of Interest}

The authors declare that they have no conflicts of interest.

\section{References}

[1] B. Divya, S. O. Fernandes, G. Sheelu, N. Shanta, P. A. L. Bharathi, and D. Chandramohan, "Limno-tolerant bacteria govern nitrate concentration in Mandovi Estuary, India," Estuarine, Coastal and Shelf Science, vol. 82, no. 1, pp. 29-34, 2009.

[2] J. J. Barrera-Alba, S. M. F. Gianesella, G. A. O. Moser, and F. M. P. S. Correa, "Influence of allochthonous organic matter on bacterioplankton biomass and activity in a eutrophic, subtropical estuary," Estuarine, Coastal and Shelf Science, vol. 82, no. 1, pp. 84-94, 2009.

[3] F. A. Esteves, A. Caliman, J. M. Santangelo, R. D. Guariento, V. F. Farjalla, and R. L. Bozelli, "Neotropical coastal lagoons: an appraisal of their biodiversity, functionings, threats and conservation management," Brazilian Journal of Biology, vol. 68, no. 4S, pp. 967-981, 2008.

[4] B. Kjerfve, Coastal Lagoon Processes, Elsevier Science B.V., Amsterdam, Netherlands, 1994.

[5] D. Sigge, Freshwater Microbiology: Biodiversity and Dynamic Interactions of Microorganisms in the Aquatic Environment, Vol. 1, John Wiley \& Sons Ltd., Chichester, UK, 2005.

[6] R. G. Wetzel, Limnology, Saunders Publishing, Philadelphia, PA, USA, 1982.

[7] F. Azam, T. Fenchel, J. G. Field, J. S. Gray, L. A. Meyer-Reil, and F. Thingstad, "The ecological role of water-column microbes in the sea," Marine Ecology Progress Series, vol. 10, pp. 257-263, 1983.
[8] M. Warkentin, H. M. Freese, and R. Schumann, "Bacterial activity and bacterioplankton diversity in the eutrophic river Warnow-direct measurement of bacteria 1 growth efficiency and its effect on carbon utilization," Microbial Ecology, vol. 61, no. 1, pp. 190-200, 2011.

[9] D. A. Caron, E. L. Lim, R. W. Sanders, M. R. Dennett, and U. G. Berninger, "Responses of bacterioplankton and phytoplankton to organic carbon and inorganic nutrient additions in contrasting oceanic ecosystems," Aquatic Microbial Ecology, vol. 22, pp. 175-184, 2000.

[10] M. P. Hoch and D. A. Bronk, "Bacterioplankton nutrient metabolism in the Eastern Tropical North Pacific," Journal of Experimental Marine Biology and Ecology, vol. 349, no. 2, pp. 390-404, 2007.

[11] L. R. Pomeroy and D. Deibel, "Temperature regulation of bacterial activity during the spring bloom in newfoundland coastal waters," Science, vol. 233, no. 4761, pp. 359-361, 1986.

[12] M. M. Sala, F. Peters, J. M. Gasol, C. Pedrós-Alió, C. Marrase, and D. Vaque, "Seasonal and spatial variations in the nutrient limitation of bacterioplankton growth in the northwestern Mediterranean," Aquatic Microbial Ecology, vol. 27, pp. 4756, 2002.

[13] D. Ichinotsuka, T. Katan, H. Takeoka, and S. Nakano, "Effects of nutrient supplies on the growth rates of planktonic bacteria in Uchiumi Bay, Japan," Aquatic Biology, vol. 9, pp. 123-130, 2010.

[14] C. A. Carlson, S. J. Giovannoni, D. A. Hansel et al., "Effect of nutrient amendments on bacterioplankton production, community structure, and DOC utilization in the northwestern Sargasso Sea," Aquatic Microbial Ecology, vol. 30, pp. 19-36, 2002.

[15] M. J. Church, D. A. Hutchins, and H. W. Ducklow, "Limitation of bacterial growth by dissolved organic matter and iron in the Southern Ocean," Applied and Environmental Microbiology, vol. 66, no. 2, pp. 455-466, 2000.

[16] S. P. Donachie, R. James, J. R. Christian, and D. M. Karl, "Nutrient regulation of bacterial production and ectoenzyme activities in the subtropical North Pacific Ocean," Deep Sea Research Part II: Topical Studies in Oceanography, vol. 48, no. 8-9, pp. 1719-1732, 2001.

[17] L. R. Pomeroy, J. E. Sheldon, W. M. Sheldon Jr., and F. Peters, "Limits to growth and respiration of bacterioplankton in the Gulf of Mexico," Marine Ecology Progress Series, vol. 117, pp. 259-268, 1995.

[18] V. E. C. Silva, D. Franco, A. L. Fonseca, M. L. Schmitz Fontes, and A. R. Donnangelo, "Space time evolution of the trophic state of a subtropical lagoon: Lagoa da Conceição, Florianópolis Island of Santa Catarina, Brazil," $R B R H$, vol. 22, p. e10, 2017.

[19] M. L. S. Fontes and P. A. Abreu, "Spatiotemporal variation of bacterial assemblages in a shallow subtropical coastal lagoon in Southern Brazil," Microbial Ecology, vol. 58, no. 1, pp. $140-152,2009$.

[20] M. L. S. Fontes, M. T. Suzuki, M. T. Cottrell, and P. C. Abreu, "Primary production in a subtropical stratified coastal lagooncontribution of anoxygenic phototrophic bacteria," Microbial Ecology, vol. 61, no. 1, pp. 223-237, 2011.

[21] H.-T. Ng, D. M. Marques, E. Jeppesen, and M. Søndergaard, "Bacterioplankton in the littoral and pelagic zones of subtropical shallow lakes," Hidrobiologia, vol. 646, no. 1 , pp. 311-326, 2010.

[22] A. Fonseca, E. S. Braga, and B. B. Eichler, "Distribuição espacial dos nutrientes inorgânicos dissolvidos e da biomassa fitoplanctônica no sistema pelágico da Lagoa da Conceição, 
Santa Catarina, Brasil (Setembro, 2000)," Atlântica, vol. 24, pp. 69-83, 2002.

[23] M. L. S. Fontes, R. Cavellucci, A. Laurenti, E. C. Machado, M. C. Camargo, and N. Brandini, "Detection of environmental impact on variations in dissolved nutrients and Chla in the Conceição Lagoon, Florianópolis, SC, Brazil," Journal of Coastal Research, vol. 39, pp. 1407-1412, 2006.

[24] I. S. Maia, "Avaliação de lagoas de maturação modificadas com a presença de suportes e macrófitas da família Lemnaceae no tratamento de esgotos domésticos," M.S. dissertation, Universidade Federal de Santa Catarina, Florianopólis, SC, Brazil, 2008.

[25] A. L. Fonseca, "Efeito da drenagem urbana nas características físico-químicas e biológicas da água superficial na Lagoa da Conceição (Florianópolis, SC, Brasil)," Biotemas, vol. 19, pp. 7-16, 2006.

[26] K. G. Porter and Y. S. Feig, "The use of DAPI for identifying and counting aquatic microflora," Limnology and Oceanography, vol. 25, no. 5, pp. 943-948, 1980.

[27] R. Massana, J. M. Gasol, P. K. Bjornsen et al., "Measurement of bacterial size via image analysis of epifluorescence preparations: description of an inexpensive system and solutions to some of the most common problems," Scientia Marina, vol. 61, no. 3, pp. 397-407, 1997.

[28] S. Norland, "The relationship between biomass and volume of bacteria," in Handbook of Methods in Aquatic Microbial Ecology, P. F. Kemp, B. F. Sherr, E. B. Sherr, and J. J. Cole, Eds., Lewis Publishers, Boca Raton, FL, USA, 1993.

[29] C. A. Carlson and H. W. Ducklow, "Growth of bacterioplankton and consumption of dissolved organic carbon in the Sargasso Sea," Aquatic Microbial Ecology, vol. 10, pp. 69-85, 1996.

[30] A. J. Underwood, Experiments in Ecology: Their Logical Design and Interpretation Using Analysis of Variance, Cambridge University Press, Cambridge, UK, 2006.

[31] J. H. Zar, Biostatistical Analysis, Prentice Hall, Englewood Cliffs, NJ, USA, 1996.

[32] J. M. Gasol, P. A. Giorgio, R. Massana, and C. M. Duarte, "Active versus inactive bacteria: size-dependence in a coastal marine plankton community," Marine Ecology Progress Series, vol. 128, pp. 91-97, 1995.

[33] G. Corno and K. Jürgens, "Direct and indirect effects of protist predation on population size structure of a bacterial strain with high phenotypic plasticity," Applied and Environmental Microbiology, vol. 72, no. 1, pp. 78-86, 2006.

[34] K. Jürgens and H. Gude, "The potential importance of grazing-resistant bacteria in planktonic systems," Marine Ecology Progress Series, vol. 112, pp. 169-188, 1994.

[35] K. Jürgens and C. Matz, "Predation as a shaping force for the phenotypic and genotypic composition of planktonic bacteria," Antonie van Leeuwenhoek, vol. 81, no. 1-4, pp. 413-434, 2002.

[36] L. Berdjeb, T. Pollet, I. Domaizon, and S. Jacquet, "Effect of grazers and viruses on bacterial community structure and production in two contrasting trophic lakes," BMC Microbiology, vol. 11, p. 88, 2011.

[37] M. G. Weinbauer and F. Rassoulzadegan, "Are viruses driving microbial diversification and diversity?," Environmental Microbiology, vol. 6, no. 1, pp. 1-11, 2004.

[38] M. G. Weinbauer, K. Hornák, J. Jezbera, J. Nedoma, J. R. Dolan, and K. Šimek, "Synergistic and antagonistic effects of viral lysis an protistan grazing on bacterial biomass, production and diversity," Environmental Microbiology, vol. 9, no. 3, pp. 777-788, 2007.
[39] D. J. Suggett, N. Stambler, O. Prásil et al., "Nitrogen and phosphorus limitation of oceanic microbial growth during spring in the Gulf of Aqaba," Aquatic Microbial Ecology, vol. 56, pp. 227-239, 2009.

[40] C. J. Williams, P. J. Lavrentyev, and F. J. Jochem, "Bottom-up and top-down control of heterotrophic bacterioplankton growth in a phosphorus-depleted subtropical estuary, Florida Bay, USA," Marine Ecology Progress Series, vol. 372, pp. 7-18, 2008.

[41] J. J. Cole, S. Findlay, and M. L. Pace, "Bacterial production in fresh and saltwater ecosystems: a cross-system overview," Marine Ecology Progress Series, vol. 43, pp. 1-10, 1988.

[42] A. L. Cuevas, J. K. Egge, F. T. Thingstad, and B. Töpper, "Organic carbon and mineral nutrient limitation of oxygen consumption, bacterial growth and efficiency in the Norwegian Sea," Polar Biology, vol. 34, no. 6, pp. 871-882, 2011.

[43] S. Drakare, P. Blomqvist, A. K. Bergstrom, and M. Jansson, "Primary production and phytoplankton composition in relation to DOC input and bacterioplankton production in humic Lake Ortrasket," Freshwater Biology, vol. 47, no. 1, pp. 41-52, 2002.

[44] J. Karlsson, M. Jansson, and A. Jonsson, "Similar relationships between pelagic primary and bacterial production in clearwater and humic lakes," Ecology, vol. 83, no. 10, pp. 29022910, 2002.

[45] D. L. Kirchman, "The uptake of inorganic nutrients by heterotrophic bacteria," Microbial Ecology, vol. 28, no. 2, pp. 255-271, 1994.

[46] M. M. Mills, C. M. Moore, R. Langlois et al., "Nitrogen and phosphorus co-limitation of bacterial productivity and growth in the oligotrophic subtropical North Atlantic," Limnology and Oceanography, vol. 53, no. 2, pp. 824-834, 2008.

[47] G. A. F. Flaten, T. Castberg, T. Tanaka, and F. Thingstad, "Interpretation of nutrient-enrichment bioassays by looking at sub-populations in a marine bacterial community," Aquatic Microbial Ecology, vol. 33, pp. 11-18, 2003.

[48] M. L. Pace and J. J. Cole, "Comparative and experimental approaches to top-down and bottom-up regulation of bacteria," Microbial Ecology, vol. 28, no. 2, pp. 181-193, 1994.

[49] R. E. Carlson, "A trophic state index for lakes," Limnology and Oceanography, vol. 22, no. 2, pp. 361-369, 1977.

[50] W. K. Dodds and J. J. Cole, "Expanding the concept of trophic state in aquatic ecosystems: it's not just the autotrophs," Aquatic Sciences, vol. 69, no. 4, pp. 427-439, 2007.

[51] B. Biddanda and J. B. Cotner, "Love handles in aquatic ecosystems: the role of dissolved organic drawdown, resuspended sediments, and terrigeous inputs in the carbon balance of Lake Michigan," Ecosystems, vol. 5, no. 5, pp. 431-445, 2002.

[52] B. J. Campbell, L. Yu, J. F. Heidelberg, and D. L. Kirchman, "Activity of abundant and rare bacteria in a coastal ocean," Proceedings of the National Academy of Sciences, vol. 108, no. 31, pp. 12776-12781, 2011.

[53] H. P. Grossart, J. Jezbera, K. Hornak, K. M. L. Hutalle, U. Buck, and K. Simek, "Top-down and bottom-up induced shifts in bacterial abundance, production and community composition in an experimentally divided humic lake," Environmental Microbiology, vol. 10, no. 3, pp. 635-652, 2008.

[54] K. Haukka, E. Kolmonen, R. Hyder et al., "Effect of nutrient loading on bacterioplankton community composition in Lake Mesocosms," Microbial Ecology, vol. 51, no. 2, pp. 137-146, 2006.

[55] R. J. Newton and K. D. McMahon, "Seasonal differences in bacterial community composition following nutrient additions in a eutrophic lake," Environmental Microbiology, vol. 13, no. 4, pp. 887-899, 2011. 


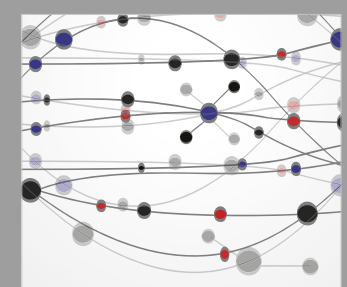

The Scientific World Journal
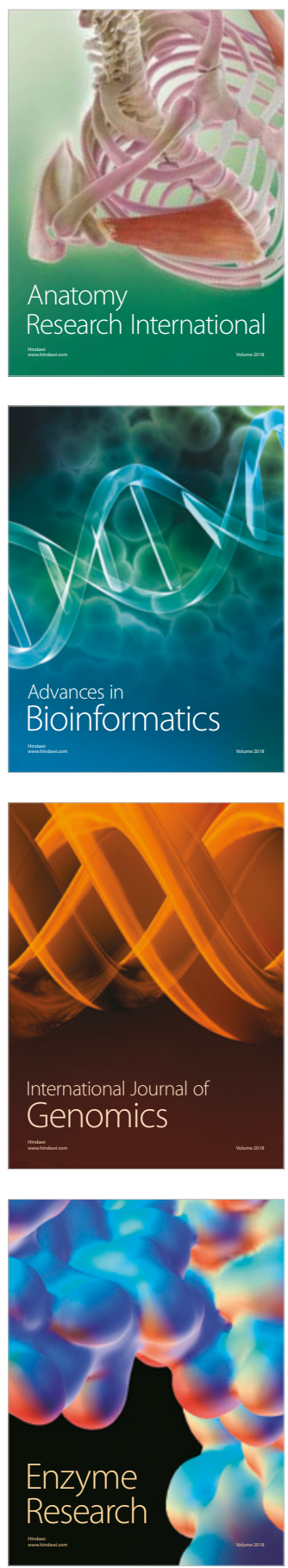
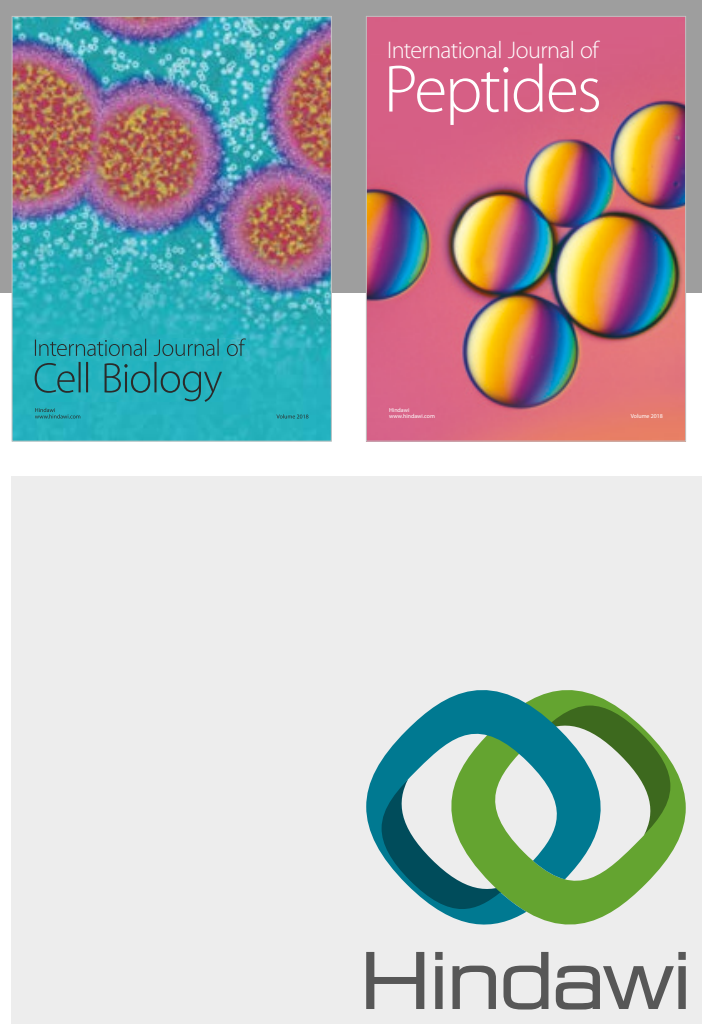

Submit your manuscripts at

www.hindawi.com
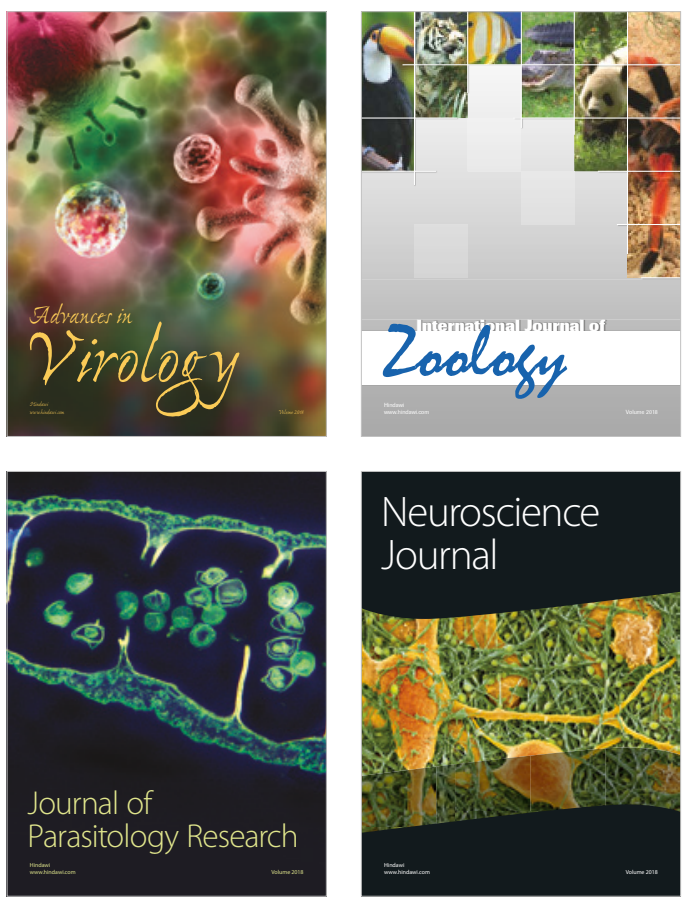
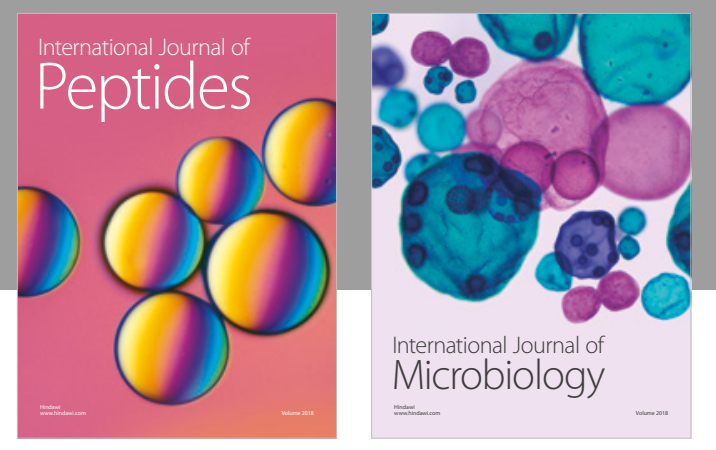

nternational Journal of Microbiology
Journal of
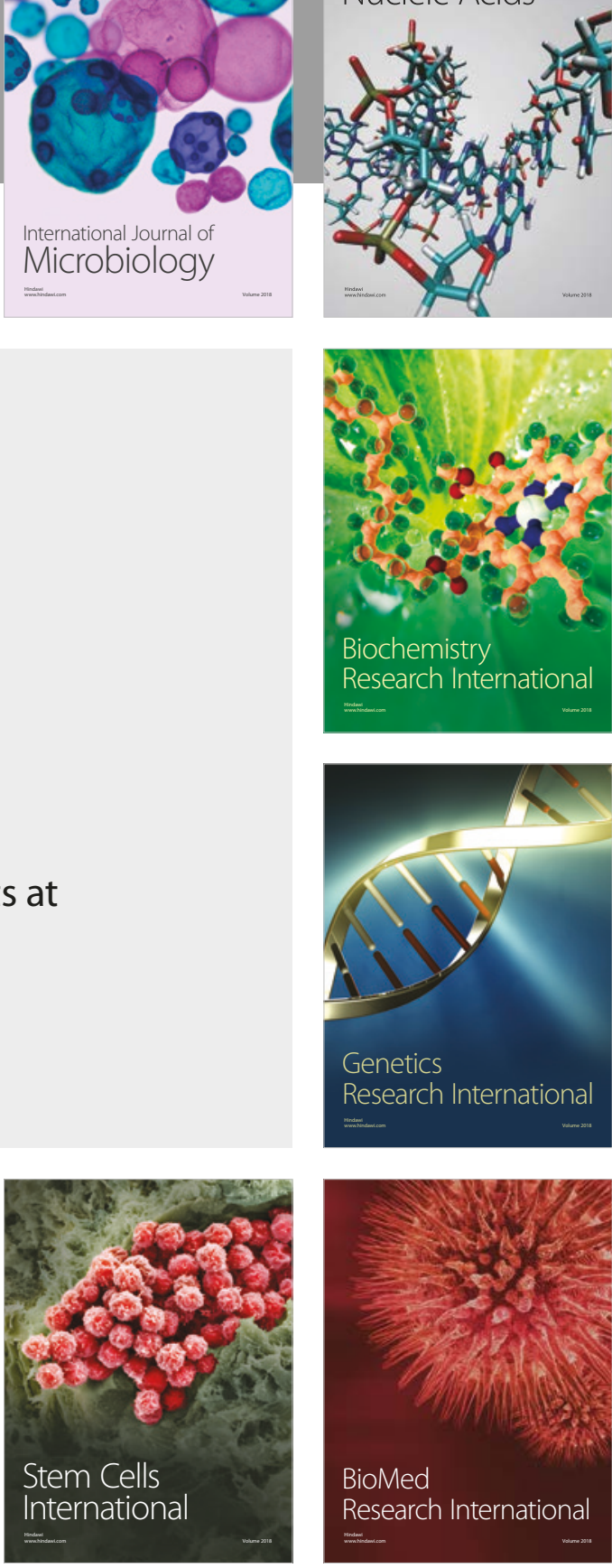
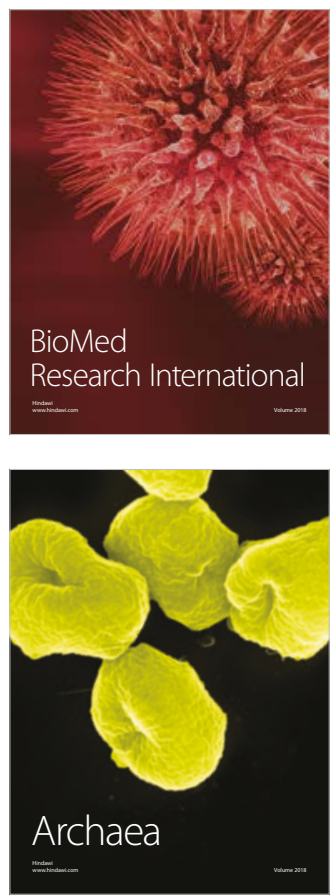